\title{
Short Selling and Executive Pay-for-Performance Sensitivity
}

\author{
Wanlin Chen \\ Management School, Jinan University, Guangzhou, China \\ Email: chenwanlinjnu@163.com
}

How to cite this paper: Chen, W.L. (2018) Short Selling and Executive Pay-for-Performance Sensitivity. American Journal of Industrial and Business Management, 8, 1007-1021.

https://doi.org/10.4236/ajibm.2018.84069

Received: March 28, 2018

Accepted: April 25, 2018

Published: April 28, 2018

Copyright $\odot 2018$ by author and Scientific Research Publishing Inc. This work is licensed under the Creative Commons Attribution International License (CC BY 4.0).

http://creativecommons.org/licenses/by/4.0/

\section{(c) (i) Open Access}

\begin{abstract}
Based on the launch of short selling in our country as the background, using the data of the a-share listed company from 2007 to 2016 in China, we built the model and empirically proved the impact of short selling on the target company executive compensation contracts. And then we discussed how the different supervision mechanism and the management rights affected their relationship. This paper finds out that the implementation of short selling improved Executive Pay-for-performance Sensitivity of the target company. In the weak supervision mechanism of listed companies, short selling can significantly improve the Executive Pay-for-performance Sensitivity, while in strong supervision mechanism of listed companies, short selling can't play a role; further from management right consideration, we found that in the higher management rights of listed companies, short selling can significantly improve its Executive Pay-for-performance Sensitivity, and in lower management rights of the listed company, short selling has no significant influence on management compensation contracts.
\end{abstract}

\section{Keywords}

Short Selling, Executive Pay-for-Performance Sensitivity

\section{Introduction}

Short selling, also known as "credit transaction", refers to the behavior of investors who meet certain conditions with their own funds or securities as collateral and sell securities by borrowing securities from securities firms and repaying the securities and interest within the agreed period. Most mature markets and some emerging markets allow short selling. However, due to the formal start of short selling in China on March 31, 2010, there are not many empirical articles of China's short selling policy effect. Moreover, domestic and foreign researches 
mainly focus on the impact of short selling on short-term behaviors such as stock market efficiency, financial information quality, and company's investment, such as Chang et al. (2014) [1], Li et al. (2015) [2], Li \& Zhang (2015) [3], which have studied the effect of short selling mechanism on the efficiency of stock pricing. Karpoff, Lou (2010) [4], Hirshleifer et al. (2011) [5], investigated the effect of short selling mechanism on the quality of financial information; Grullon et al. (2015) [6] and Jin et al. (2015) [7] examined the impact of short selling mechanism on corporate investment behavior. There is little literature on the impact of short-selling on executive pay contracts. But it is important to explore the impact of short selling in the capital market on the system of corporate governance.

The marginal contribution of this paper is to: 1) expand the research perspective of short selling mechanism. From the perspective of executive compensation contract, this paper analyzes and tests the mechanism and intrinsic effect of short selling mechanism on executive compensation contract, which provides a new research direction of short selling mechanism; 2) enrich and supplement the research on executive compensation; 3 ) provide policy implications for the corporate governance effect of short selling mechanism. Since the introduction of the financing and short selling system in March 2010, there have been a lot of disputes in theory and practice, especially in the second half of 2015. The stock market in China's capital market has pushed the short selling mechanism to the top of the market, and many investors are more inclined to believe that the short selling mechanism is the main cause of the stock market disaster in China. In this paper, based on the effect of the policy of margin test motivation, it is found that the implementation of the margin system of corporate governance, especially the improvement of executive compensation contract, has significant effect.

The remaining chapters of this paper are as follows: the second part is the literature review; the third part is the theory analysis and hypothesis; the fourth part is the research design and empirical analysis, including sample selection, data sources, set model and variable measure, the results of the regression analysis and robustness testing; the fifth part is the research conclusion and policy enlightenment.

\section{Literature Review}

In the case of short selling, when the price of a stock is overvalued for some reason, the profit-seeking investor will use the borrowed stock to carry out short selling, which will restrain the bubble of the rising stock price. When these overvalued stock prices fell as the bubble burst, short sellers bought the shares back to lenders. Existing literature on the impact of short selling mainly focuses on the price efficiency and market volatility of short selling.

Miller (1977) [8] argued that when investors viewed differences about a risk assets, short-selling restrictions made pessimistic investors out of the market. Then risk assets price only reflected optimistic investors' view on the market, 
leading to stock up, cause overestimate, thereby reducing the market pricing efficiency. Diamond et al. (1987) [9] established a short selling restriction information trader model, demonstrating that short selling restriction lowered stock pricing efficiency, as it weakens the rate of adjustment of share prices to a negative message. Chang et al. (2014) [1] found that after the stock was put into short selling, the excess return of short-selling stock could be significantly negative, while the pricing efficiency increased. Li et al. (2014) [10] found that short selling restriction led to overvaluation of stock price, and short selling could help correct overvalued share price and improve market pricing efficiency. Li et al. (2015) [2] found that the introduction of short selling has effectively improved the price discovery mechanism of China's stock market, and the pricing efficiency of the shares in short selling lists has been significantly improved.

Now research has gone from the impact on market to the effect of short selling on corporate behavior. As an indispensable link in the financial innovation chain, short selling has a great influence on the information disclosure behavior of listed companies. Christophe et al. (2010) [11] believed that short selling provides investors with a channel for profit through negative information, which will encourage investors to collect and dig negative information about enterprises and managers. The process of mining negative information by short sellers increases the risk that managers fail to disclose the positive information in time, so it will motivate managers to disclose information timely and accurately. Karpoff et al. (2010) [4], Hirshleifer et al. (2011) [5] found that short selling can restrain the financial fraud. Chen et al. (2015) [12], Fang et al. (2016) [13] found that short selling can restrain earnings management and improve the reliability of financial information. Li (2017) [14] found that the introduction of short selling significantly improved the quality of the target company's information disclosure. Zhang (2016) [15] found that listed companies would attract more attention, such as analysts, their attention would also reduce the information asymmetry, increase the cost of managers' self-interest behavior, thus improve the quality of information disclosure of company.

The study of Massa et al. (2012) [16] found that the relaxation of short selling was conducive to the efficiency of the stock market, fully exerting the guidance and restraint of the price, and reducing the opportunistic behavior of management. In particular, after removing the short selling restriction, for the company with bad news, the use of short transaction will bring the bad news to the share price, so the function of the price discovery for bad news will cause the large shareholders of the company to implement the effective supervision of management. Hou (2017) [17] found that the relaxation of short selling control can restrain the "tunneling" behavior of large shareholders to a certain extent, and the short selling mechanism can play a role in protecting the interests of minority shareholders. Jin et al. (2015) [7] studied how the short selling mechanism affected the company's investment behavior and company value. They found that for listed company, when facing the poor investment opportunities and making the wrong decision, potential investors can inject the bad news into share price 
through the way of short selling. For reasons of their own wealth, therefore, big shareholders will be more effectively supervise company's management, so as to make the management more timely liquidation option, to enhance the value of company liquidation option is better.

\section{Theoretical Analysis and Hypothesis}

\subsection{Short Selling and Incentive Contracts for Executive Compensation}

The current incentive contract theory of executive compensation mainly includes effective contract view and rent-seeking view (Xie et al., 2012) [18]. According to the effective contract view based on the principal's perspective, the principal can design effective executive compensation contract, restrain the management opportunism behavior, and motivate the senior management to work hard (Jensen and Murphy, 1990) [19]. Therefore, compensation contracts can improve the economic efficiency, easing the principal conflicts of interest between shareholders and executives. So the contract is a valid contract, which is the so-called "effective contract". Another theory, based on the perspective of agents, holds that executives have important influence on the design of compensation contracts. Executives will use their power to seek personal interests in the design of compensation contracts, leading to the possibility that executive compensation contracts may be the result of the rent-seeking of senior executives and become part of the agency problem (Bebchuk and Fried, 2002) [20]. This is called rent-seeking. Since there are two different kinds of theoretical viewpoints, the relationship between short selling and salary performance sensitivity is theoretically analyzed based on the "rent-seeking concept" and "effective contract view". On this basis, we propose the corresponding hypothesis.

First, according to the "rent-seeking concept", executives will take advantage of potential rent-seeking opportunities to make the salary contract beneficial to them (Liu, 2017) [21]. The introduction of short selling allowed investors to short the rent-seeking behavior of management, which caused the stock to fall sharply. A sharp fall in share prices has wiped out shareholders' wealth, leading to severe regulation by big shareholders, and even leading to a loss of management status. As a result, under the pressure of margin, the motivation of management compensation was reduced.

Secondly, the assumption of effective contract theory is that the shareholders can fully understand the behavior of the operation manager and effectively supervise the behavior of the managers. Short selling provides investors with a channel to profit through negative news (Diamond and Verrecchia, 1987) [9], which encourages investors to gather and dig up negative information about companies and managers. On the one hand, it can reduce the information asymmetry between shareholders and management. On the other hand, Short selling increases the content of the shares of company stock information and stock price can reflect the fundamentals of the company and more management 
behavior. The decrease of information asymmetry and the increase of share price information can help the owner to make effective compensation contract. Therefore, short selling is conducive to the effectiveness of incentive contracts.

In the end, short selling brings a downside risk to share prices, which will lead to a fall in the share price, which not only makes the big shareholders' wealth seriously shrink, but also raises the cost of financing and the company is in trouble. So in order to avoid the serious consequences of a company by shorting, large shareholders are forced to improve corporate governance mechanism in advance, such as through more grant stock and option incentive to managers, the interests of managers and shareholders are more consistent, which in turn increases the efficiency of the remuneration contract. In conclusion, this paper believes that short selling can help to determine the compensation of management and improve the effectiveness of the compensation contract. Accordingly, this paper proposes $\mathrm{H} 1$ :

H1: short selling can improve the effectiveness of executive compensation contracts.

\subsection{Supervision Mechanism and Executive Compensation Contract}

The idea that effective corporate governance can improve the effectiveness of executive compensation incentive contracts has reached consensus in academia. Lu et al. (2011) [22] found that companies with higher internal control quality were more sensitive to executive compensation performance. Deng et al. (2015) [23] found that the board of directors with overlapping positions of the remuneration committee and the audit committee had the advantages of information, which was helpful to curb the rent-seeking of senior executives and enhance the governance of non-performance compensation. Lin et al. (2013) [24] found that compared with the company that the actual controller did not serve as a member of the remuneration committee, the actual controller of the company who was the director of the remuneration committee was more sensitive to the performance of the company.

Short selling serves as an external governance mechanism. When the supervision mechanism fails and the incentive contract for executive compensation does not work, the short selling mechanism can play a role and improve the effectiveness of the incentive contract for executive compensation. By contrast, short selling, as an alternative governance mechanism, might be less obvious if the company's mechanism works. Considering the impact of short selling and supervision mechanism, this paper puts forward the hypothesis $\mathrm{H} 2$ :

$\mathrm{H} 2$ : for companies that have weak supervision mechanism, short selling is more obvious to the improvement of executive compensation incentive contract.

\subsection{Management Rights and Executive Compensation Contracts}

The rent-seeking view of the compensation contract holds that executives will 
use its rights to make the pay contract beneficial to itself. Executives have more rights, the greater the rent-seeking opportunities, the more likely it is to make compensation contracts favourable, the effective less of the compensation incentive contracts. But this also gives room for improvement. Short selling, as an external supervision mechanism, may also play a bigger role. For executives with less management rights and fewer rent-seeking opportunities, short selling may not play an effective supervisory role. Accordingly, this paper puts forward the hypothesis $\mathrm{H} 3$ :

H3: compared with listed companies with relatively small management rights, short selling has a more obvious effect on the compensation incentive contract of the company management with larger management rights.

\section{Research Design and the Empirical Analysis}

\subsection{Research Design}

We designed the following models to test the research hypothesis of this paper:

$$
\begin{aligned}
\text { Lnpay }_{i, t}= & \alpha_{1}+\alpha_{2} * \text { Short }_{i, t}+\alpha_{3} * \text { CROA }_{i, t}+\alpha_{4} * \text { Short }_{i, t} \\
& * \text { CROA }_{i, t}+\text { Controls }_{i, t}+\sum \text { Industry }+\sum \text { Year }+\varepsilon_{i, t}
\end{aligned}
$$

The variable LnPay is interpreted to represent the level of executives compensation. Referred to $\mathrm{Wu}$ (2010) [25], we used the natural logarithm of the total remuneration of the top three executive, we do not use a particular executive (CEO) compensation measure executive pay. Short $\times C R O A$ is needed to focus on in our paper, referred to Hou \& Jin (2017) [17], when the shares of listed companies in the year was allowed to sell short, the Short is equal to 1, or equal to zero. $C R O A$ is an indicator of company performance. Referred to the practices of Zhang et al. (2013) [26]. We use operating profit/total assets to measure the company's performance level. According to H1, we expect that the coefficient of Short $\times C R O A$ is greater than 0 .

In addition to the above variables, we also set the grouping variable: 1) the supervision mechanism of Sup, referred to Fang and Jin (2013) [27] research methods, we select the first big shareholder's proportion (Top), the second to fifth largest shareholder's proportion (ranked by $2-5$ ), the independent directors proportion (Ibr), institutional investors holding (Ins), the combination of director and general manager (Ma), the board size (Bsize), the size of the board of supervisors (Susize) as the index of supervision mechanism. According to the method of Clifford et al. (2014), we standardize the indicators first, and then take the equal weights of indicators to evaluate the strength of the company's supervision mechanism; 2) management rights (JR), referring to the research method of Lu Rui (2008), we use the combination of director and general manager to evaluate the management rights.

In the study of executive compensation, existing literature tends to control the scale of the company's assets, financial leverage, growth, whether executives shareholding, the first big shareholder's stake, the independent directors propor- 
tion and corporate property and other factors. To this end, we set the natural logarithm of assets (Size), asset-liability Ratio (Lev), sales Growth (Growth), whether executives holding share (MSHD), the proportion of the first largest shareholder (Fsthd), the independent directors proportion (Ratio) and the nature of the enterprise (Soe) to control these factors.

The short selling in China was officially launched on March 31, 2010. The first batch of 90 listed company shares entered the subject of margin trading. After that, it has undergone five major expansion and adjustment. As of December 31, 2016, there were 950 shares of short-selling target (Table 1).

The data of this paper are derived from CSMAR database and WIND database, and the research samples are all a-share listed companies in Shanghai and Shenzhen stock exchanges. taking into account the data restriction of relevant variables required by the model and the time to relax short selling control, the sample period of this paper is from 2007 to 2016.According to the following criteria, this paper carries out data screening: 1) taking into account the special nature of the financial industry, excluding financial industry companies; 2) take out the firm that entered the set and then quit; 3) to eliminate the ST, PT listed company; 4) remove samples with missing indicators. Through the above screening process, there were 12,496 samples, of which 2775 were sold short. In order to control the influence of the extreme value, all variables involved in the model were handled according to the criteria of $1 \%$ Winsorize. The sample distribution is as follows (Table 2).

\subsection{The Empirical Analysis}

Table 3 gives the descriptive statistics of all the other variables except the industry and annual dummy variables involved in the model. The mean, maximum, minimum, and standard deviation of LnPay are 14.19959, 17.3090, 10.3080, and 0.7643 , respectively. The mean, maximum, minimum, and standard deviation of Short are $0.2221,1.0000,0.0000$, and 0.4157 , respectively. The mean, maximum, minimum, and standard deviation of CROA are 0.0534, 0.5864, -0.4067 , and 0.0840 , respectively. It can be seen that there are significant differences in executive pay levels, control chain length, and performance levels among different companies. This provides the basis for studying the relationship among the control chain length, pay level and pay- performance sensitivity.

Table 1. The expansion of short selling and the statistics of elimination.

\begin{tabular}{cccc}
\hline Year & List of short selling & Newly increased & Culled \\
\hline 2010 & 90 & 96 & 6 \\
2011 & 278 & 189 & 1 \\
2013 & 700 & 482 & 60 \\
2014 & 899 & 218 & 19 \\
2015 & 891 & 0 & 8 \\
2016 & 950 & 77 & 18 \\
\hline
\end{tabular}

Data source: Wind database. 
Table 2. Sample distribution.

\begin{tabular}{ccc}
\hline Year & Number of observation & Short selling term \\
\hline 2007 & 800 & 0 \\
2008 & 850 & 0 \\
2009 & 953 & 0 \\
2010 & 1140 & 55 \\
2011 & 1261 & 189 \\
2012 & 1357 & 187 \\
2013 & 1378 & 430 \\
2014 & 1466 & 543 \\
2015 & 1576 & 680 \\
2016 & 1715 & 691 \\
合计 & 12496 & 2775 \\
\hline
\end{tabular}

Table 3. Variable description.

\begin{tabular}{cccccc}
\hline Variable & Obs & Mean & Std.ev & Min & Ma \\
\hline LnPay & 12496 & 14.1959 & 0.7643 & 10.3080 & 17.3090 \\
Short & 12496 & 0.2221 & 0.4157 & 0.0000 & 1.0000 \\
Soe & 12496 & 0.5186 & 0.4997 & 0.0000 & 1.0000 \\
MSHD & 12496 & 0.7169 & 0.4505 & 0.0000 & 1.0000 \\
Fsthd & 12496 & 0.3718 & 0.1605 & 0.0840 & 0.8941 \\
Lev & 12496 & 0.5175 & 1.7759 & 0.0075 & 1.6810 \\
Growth & 12496 & 0.2446 & 2.8509 & -0.8099 & 5.7750 \\
Ratio & 12496 & 0.3698 & 0.0555 & 0.0909 & 0.8000 \\
Size & 12496 & 22.3958 & 1.3180 & 10.8422 & 28.5087 \\
CROA & 12496 & 0.0534 & 0.0840 & -0.4067 & 0.5864 \\
\hline
\end{tabular}

Table 4 lists the correlation analysis results among the variables. It can be seen that: executive pay is positively related to short-selling, corporate performance, company size, proportion of independent directors, and shares held by senior executives, and negatively correlated with asset-liability ratio, revenue growth rate, and corporate nature. According to the univariate test results of each variable, the absolute value of the correlation coefficient between variables is below 0.5 , indicating that the variables are independent of each other and there is no multicollinearity.

Table 5 gives the regression analysis results for hypothesis H1. If H1 stands, the coefficient of Short $\times C R O A$ should be significantly positive. Regression 1 is the basic regression result, while regression 2 is the regression result with the annual effect and the industry effect controlled. From the above table, it can be seen that the Short $\times C R O A$ coefficient is significant at $1 \%$, regardless of whether 
Table 4. Spearson correlation coefficient.

\begin{tabular}{|c|c|c|c|c|c|c|c|c|c|c|}
\hline Variable & LnPay & Short & $C R O A$ & Lev & Growth & Size & Soe & Ratio & MSHD & Fsthd \\
\hline LnPay & 1.000 & & & & & & & & & \\
\hline Short & $0.303^{* * *}$ & 1.000 & & & & & & & & \\
\hline$C R O A$ & $0.199^{* * *}$ & 0.008 & 1.000 & & & & & & & \\
\hline Lev & $-0.056^{* * *}$ & -0.01 & $-0.243^{\star * *}$ & 1.000 & & & & & & \\
\hline Growth & $-0.021^{\star *}$ & $-0.017^{\star}$ & $0.041^{* * *}$ & -0.001 & 1.000 & & & & & \\
\hline Size & $0.433^{\star * *}$ & $0.374^{\star * *}$ & 0.001 & $-0.063^{* * *}$ & $-0.025^{\star \star \star}$ & 1.000 & & & & \\
\hline Soe & $-0.023^{\star *}$ & $0.040^{\star * *}$ & $-0.114^{* * *}$ & 0.010 & $-0.032^{\star * *}$ & $0.308^{* * *}$ & 1.000 & & & \\
\hline Ratio & $0.036^{* * *}$ & $0.081^{\star * *}$ & $-0.033^{* * *}$ & $0.017^{*}$ & $0.016^{*}$ & $0.081^{* * *}$ & $-0.044^{* * *}$ & 1.000 & & \\
\hline MSHD & $0.107^{\star * *}$ & $0.050^{* * *}$ & $0.044^{* * *}$ & -0.003 & 0.001 & -0.011 & $-0.204^{* * *}$ & 0.004 & 1.000 & \\
\hline Fsthd & 0.004 & -0.009 & $0.100^{* * *}$ & 0.006 & -0.012 & $0.265^{\star * *}$ & $0.231^{\star * *}$ & $0.040^{* * *}$ & $-0.235^{\star * *}$ & 1.000 \\
\hline
\end{tabular}

Table 5. Short-selling and pay-performance sensitivity of the management.

\begin{tabular}{|c|c|c|}
\hline & Model (1) & Model (2) \\
\hline & LnPay & LnPay \\
\hline \multirow[t]{2}{*}{ Short } & $0.206^{\star * *}$ & $0.0811^{\star * *}$ \\
\hline & (11.08) & $(4.23)$ \\
\hline \multirow[t]{2}{*}{$C R O A$} & $1.672^{\star * *}$ & $1.863^{\star * *}$ \\
\hline & $(21.25)$ & $(24.50)$ \\
\hline \multirow[t]{2}{*}{ Short $\times C R O A$} & $0.849^{\star * *}$ & $0.774^{* * *}$ \\
\hline & $(4.36)$ & $(4.15)$ \\
\hline \multirow[t]{2}{*}{ Lev } & $0.00908^{* * *}$ & $0.0131^{\star * *}$ \\
\hline & $(2.68)$ & $(4.04)$ \\
\hline \multirow[t]{2}{*}{ Growth } & $-0.00541^{* * *}$ & $-0.00521^{\star * \star}$ \\
\hline & $(-2.65)$ & $(-2.68)$ \\
\hline \multirow[t]{2}{*}{ Size } & $0.257^{* * *}$ & $0.241^{\star \star \star}$ \\
\hline & $(49.42)$ & $(46.78)$ \\
\hline \multirow[t]{2}{*}{ Soe } & $-0.170^{* * *}$ & $-0.0999^{* * *}$ \\
\hline & $(-13.32)$ & $(-7.93)$ \\
\hline \multirow[t]{2}{*}{ Ratio } & -0.0815 & $-0.224^{* *}$ \\
\hline & $(-0.77)$ & $(-2.21)$ \\
\hline \multirow[t]{2}{*}{ MSHD } & $0.0881^{\star * *}$ & $0.0659^{* * *}$ \\
\hline & $(6.52)$ & $(5.07)$ \\
\hline \multirow[t]{2}{*}{ Fsthd } & $-0.450^{* * *}$ & $-0.385^{\star * *}$ \\
\hline & $(-11.39)$ & $(-10.11)$ \\
\hline \multirow[t]{2}{*}{ _cons } & $8.521^{* * *}$ & $8.167^{\star * *}$ \\
\hline & $(74.12)$ & $(66.40)$ \\
\hline$Y E A R$ & NO & YES \\
\hline INDUSTRY & NO & YSE \\
\hline$N$ & 12496 & 12496 \\
\hline Adj_R^2 & 0.2797 & 0.3461 \\
\hline
\end{tabular}

\footnotetext{
${ }^{*} p<0.10,{ }^{* *} p<0.05,{ }^{* * *} p<0.01$.
} 
the annual effect and the industry effect are controlled. This shows that the short-selling has significantly improved the pay-performance sensitivity of the management in the target company. Thus, $\mathrm{H} 1$ is supported.

Table 6 exhibits the empirical results of hypothesis $\mathrm{H} 2$ grouped using a supervisory mechanism. It can be seen that when Sup $=1$, the coefficient of Short $\times C R O A$ is 0.318 , but not significant. When Sup $=0$, the coefficient is 1.028 , and is significant at $1 \%$. When Sup $=0$, the coefficient is greater than that at Sup $=1$. It can be deduced that short selling can improve the pay-performance sensitivity

Table 6. Short-selling, the supervisory mechanism and pay-performance sensitivity of the management.

\begin{tabular}{|c|c|c|}
\hline & \multicolumn{2}{|c|}{ LnPay } \\
\hline & Sup $=1$ & Sup $=0$ \\
\hline \multirow[t]{2}{*}{ Short } & $0.0981^{\star * *}$ & $0.0781^{* * *}$ \\
\hline & $(3.79)$ & $(2.75)$ \\
\hline \multirow[t]{2}{*}{$C R O A$} & $2.020^{* * *}$ & $1.486^{\star * *}$ \\
\hline & $(15.28)$ & (15.19) \\
\hline \multirow[t]{2}{*}{ Short $\times C R O A$} & 0.318 & $1.028^{* * *}$ \\
\hline & $(1.28)$ & $(3.54)$ \\
\hline \multirow[t]{2}{*}{ Lev } & $-0.244^{\star * *}$ & $0.0136^{\star * *}$ \\
\hline & $(-4.89)$ & $(4.06)$ \\
\hline \multirow[t]{2}{*}{ Growth } & -0.00323 & $-0.0129^{\star * *}$ \\
\hline & $(-1.51)$ & $(-2.92)$ \\
\hline \multirow[t]{2}{*}{ Size } & $0.230^{\star * *}$ & $0.273^{* * *}$ \\
\hline & $(30.41)$ & $(31.20)$ \\
\hline \multirow[t]{2}{*}{ Soe } & $-0.130^{\star * *}$ & $-0.0762^{* * *}$ \\
\hline & $(-7.34)$ & $(-4.07)$ \\
\hline \multirow[t]{2}{*}{ Ratio } & $-0.407^{* * *}$ & -0.0917 \\
\hline & $(-3.26)$ & $(-0.52)$ \\
\hline \multirow[t]{2}{*}{ MSHD } & $0.0677^{\star * *}$ & $0.0671^{\star * *}$ \\
\hline & $(4.08)$ & $(3.23)$ \\
\hline \multirow[t]{2}{*}{ Fsthd } & $-0.410^{* * *}$ & $-0.465^{\star \star *}$ \\
\hline & $(-7.93)$ & $(-7.65)$ \\
\hline \multirow[t]{2}{*}{ _cons } & $8.542^{\star \star \star}$ & $7.538^{\star * *}$ \\
\hline & (49.89) & (35.39) \\
\hline$Y E A R$ & YES & YES \\
\hline INDUSTRY & YES & YES \\
\hline$N$ & 6715 & 5781 \\
\hline Adj_R^2 & 0.3225 & 0.3591 \\
\hline
\end{tabular}

${ }^{*} p<0.10,{ }^{* *} p<0.05,{ }^{* *} p<0.01$. 
in the listed company, which is weak in the supervisory mechanism, and will have no significant effect on the listed companies with strong supervisory mechanisms. For this reason, $\mathrm{H} 2$ is certified.

Table 7 shows the empirical results of hypothesis $\mathrm{H} 3$ grouped using managerial power. It can be seen that the coefficient of Short $\times C R O A$ is 0.899 and significant at $1 \%$ in the group with higher managerial power, while being 0.793 (less than 0.899 , not significant) in the group with lower managerial power. This shows that the short-selling promotes the pay-performance sensitivity of the management in the companies with higher managerial power, and has no significant effect on the latter with relatively lower managerial power. $\mathrm{H} 3$ is validated.

Table 7. Short-selling, managerial power and ay-performance sensitivity of the management.

\begin{tabular}{|c|c|c|}
\hline & \multicolumn{2}{|c|}{ LnPay } \\
\hline & $\mathrm{JR}=1$ & $\mathrm{JR}=2$ \\
\hline \multirow[t]{2}{*}{ Short } & $0.0951^{\star *}$ & $0.0824^{* * *}$ \\
\hline & $(2.12)$ & $(3.90)$ \\
\hline \multirow[t]{2}{*}{$C R O A$} & $2.252^{\star * *}$ & $1.828^{* * *}$ \\
\hline & (12.11) & $(21.68)$ \\
\hline \multirow[t]{2}{*}{ Short $\times C R O A$} & 0.430 & $0.793^{* * *}$ \\
\hline & $(1.00)$ & $(3.84)$ \\
\hline \multirow[t]{2}{*}{ Lev } & $0.0456^{* * *}$ & 0.00239 \\
\hline & (6.77) & $(0.63)$ \\
\hline \multirow[t]{2}{*}{ Growth } & $-0.0166^{* * *}$ & -0.00350 \\
\hline & $(-2.97)$ & $(-1.70)$ \\
\hline \multirow[t]{2}{*}{ Size } & $0.296^{* * *}$ & $0.233^{* * *}$ \\
\hline & $(23.57)$ & $(40.89)$ \\
\hline \multirow[t]{2}{*}{ Soe } & $-0.133^{* * *}$ & $-0.0749^{\star * *}$ \\
\hline & $(-4.11)$ & $(-5.38)$ \\
\hline \multirow[t]{2}{*}{ Ratio } & -0.192 & $-0.292^{\star}$ \\
\hline & $(-0.94)$ & $(-2.50)$ \\
\hline \multirow[t]{2}{*}{ MSHD } & 0.0353 & $0.0630^{\star * *}$ \\
\hline & $(1.03)$ & $(4.49)$ \\
\hline \multirow[t]{2}{*}{ Fsthd } & $-0.506^{* * *}$ & $-0.371^{* * *}$ \\
\hline & $(-5.77)$ & $(-8.72)$ \\
\hline \multirow[t]{2}{*}{ _cons } & $7.529^{* * *}$ & $8.211^{* * *}$ \\
\hline & $(24.97)$ & $(60.71)$ \\
\hline$Y E A R$ & YES & YES \\
\hline INDUSTRY & YES & YES \\
\hline$N$ & 2437 & 10059 \\
\hline Adj_R^2 & 0.3687 & 0.3481 \\
\hline
\end{tabular}

${ }^{*} p<0.10,{ }^{* *} p<0.05,{ }^{* *} p<0.01$. 
With regard to the robustness test, the followings are carried out: Considering the impact of the limited pay order that was implemented in 2015, all hypotheses in this paper are processed by hierarchical regression and robustness test before and after the limited pay order. The results in Tables 8-10 show that the coefficient

Table 8. Short-selling and pay-performance sensitivity of the management.

\begin{tabular}{ccc}
\hline & Year $\geq 2015$ & Year $<2015$ \\
\hline Short & $0.1163^{* * *}$ & $0.0576^{* *}$ \\
& $(4.3148)$ & $(2.0389)$ \\
CROA & $1.7714^{* * *}$ & $1.8652^{* * *}$ \\
& $(8.7365)$ & $(22.3636)$ \\
Short $\times$ CROA & $0.6810^{* *}$ & $0.7688^{* * *}$ \\
$\mathrm{~N}$ & $(2.2250)$ & $(3.0079)$ \\
Adj_R^2 & 3291 & 9205 \\
\hline
\end{tabular}

${ }^{*} p<0.10,{ }^{* *} p<0.05,{ }^{* * *} p<0.01$.

Table 9. Short-selling, the supervisory mechanism and pay-performance sensitivity of the management.

\begin{tabular}{ccccc}
\hline & \multicolumn{2}{c}{ Sup $=0$} & \multicolumn{2}{c}{ Sup $=1$} \\
\hline Short & $0.0777^{* *}$ & $0.0925^{* *}$ & $0.1544^{* * *}$ & $0.0640^{*}$ \\
& $(2.0550)$ & $(2.0491)$ & $(4.0279)$ & $(1.7731)$ \\
CROA & $1.5722^{* * *}$ & $1.4298^{* * *}$ & $1.8103^{* * *}$ & $2.0238^{* * *}$ \\
& $(5.9201)$ & $(13.2604)$ & $(5.6948)$ & $(13.7661)$ \\
Short $\times$ CROA & $0.9733^{* *}$ & $0.8740^{* *}$ & 0.3644 & 0.3745 \\
& $(2.2928)$ & $(1.9855)$ & $(0.8121)$ & $(1.1760)$ \\
$N$ & 1605 & 4176 & 1686 & 5029 \\
Adj_R^2 & 0.2686 & 0.3448 & 0.2869 & 0.3150 \\
\hline
\end{tabular}

${ }^{*} p<0.10,{ }^{* *} p<0.05,{ }^{* * *} p<0.01$.

Table 10. Short-selling, managerial power and ay-performance sensitivity of the management.

\begin{tabular}{ccccc}
\hline \multicolumn{3}{c}{$\mathrm{JR}=2$} & \multicolumn{2}{c}{$\mathrm{JR}=1$} \\
\hline \multirow{2}{*}{ Short } & Year $\geq 2015$ & Year $<2015$ & Year $\geq 2015$ & Year $\leq 2015$ \\
& $0.1413^{* * *}$ & 0.0344 & 0.0180 & $0.1893^{* * *}$ \\
\multirow{2}{*}{ CROA } & $(4.7168)$ & $(1.1214)$ & $(0.2777)$ & $(2.9234)$ \\
& $1.7173^{* * *}$ & $1.8404^{* *}$ & $1.8827^{* * *}$ & $2.3084^{* * *}$ \\
\multirow{2}{*}{ Short $\times$ CROA } & $(7.2197)$ & $(20.0492)$ & $(4.5546)$ & $(7.8923)$ \\
& $0.5914^{*}$ & $0.9418^{* * *}$ & 1.1099 & -0.3650 \\
$N$ & $(1.7009)$ & $(3.3629)$ & $(1.5608)$ & $(-0.5812)$ \\
Adj_R^2 & 2516 & 7543 & 775 & 1662 \\
\hline
\end{tabular}

${ }^{*} p<0.10,{ }^{* *} p<0.05,{ }^{* *} p<0.01$. 
of Short $\times C R O A$ is mostly significant. Therefore, after considering these factors, the results of this paper are still valid.

\section{Conclusions and Recommendations}

Short selling is a kind of market trading mechanism, and it has a lot of research on the stability of the market and the price discovery. Since the stock price decline caused by short selling will affect the interests of large shareholders, this paper uses the removal of short selling restriction as an external supervision mechanism. In March 2010, China officially launched the short selling system, and the experiment of relaxing short selling control in China has played a role in Executive Pay-for-Performance Sensitivity and whether the effect of this governance effect is different under different supervision mechanisms and management rights has become a research issue in this paper. This paper adopts the a-share listed companies listed in Shanghai and Shenzhen of China from 2007 to 2015 as the research samples, and examines the mentioned issues with the help of relaxing short selling control. The research of this paper finds that the relaxation of short selling control improves the sensitivity of the management compensation performance of listed companies to a certain extent. Secondly, short selling is an external governance mechanism. When other supervision mechanisms fail to play an effective governance role, short selling can effectively promote the improvement of management compensation performance sensitivity. Again, short selling is more likely to promote the sensitivity of executive compensation performance of listed companies with higher management rights than those with effective checks and balances and low management rights.

\section{References}

[1] Chang, E.C., Luo, Y. and Ren, J. (2014) Short-Selling, Margin-Trading, and Price Efficiency: Evidence from the Chinese Market. Journal of Banking \& Finance, 48, 411-424. https://doi.org/10.1016/j.jbankfin.2013.10.002

[2] Li, Z., Chen, C. and Lin, B. (2015) Does the Short-Selling Mechanism Improve the Pricing Efficiency of China's Stock Market?_Evidence Based on Natural Experiments. Economic Research Journal, No. 4, 165-177.

[3] Li, Y. and Zhang, L. (2015) Short Selling Pressure, Stock Price Behavior, and Management Forecast Precision: Evidence from a Natural Experiment. Journal of Accounting Research, 53, 79-117. https://doi.org/10.1111/1475-679X.12068

[4] Karpoff, J.M. and Lou, X. (2010) Short Sellers and Financial Misconduct. Journal of Finance, 65, 1879-1913. https://doi.org/10.1111/j.1540-6261.2010.01597.x

[5] Hirshleifer, D., Teoh, S.H. and Yu, J.J. (2011) Short Arbitrage, Return Asymmetry, and the Accrual Anomaly. Review of Financial Studies, 24, 2429-2461.

https://doi.org/10.1093/rfs/hhr012

[6] Grullon, G., Michenaud, S. and Weston, J.P. (2015) The Real Effects of Short-Selling Constraints. Review of Financial Studies, 28, 1737-1767. https://doi.org/10.1093/rfs/hhv013

[7] Jin, Q., Hou, Q. and Li, G. (2015) Relax Short Selling Control, Company Investment Decision and Option Value. Economic Research, No. 10, 76-88. 
[8] Miller, E.M. (1977) Risk, Uncertainty, and Divergence of Opinion. Journal of Finance, 32, 1151-1168. https://doi.org/10.1111/j.1540-6261.1977.tb03317.x

[9] Diamond, D.W. and Verrecchia, R.E. (1987) Constraints on Short-Selling and Asset Price Adjustment to Private Information. Journal of Financial Economics, 18, 277-311. https://doi.org/10.1016/0304-405X(87)90042-0

[10] Li, K., Xiu, L. and Zhu, W. (2014) Short Selling Restriction and Stock Mispricing-Evidence of the Margin Lending System. Economic Research Journal, No. 10, 165-178.

[11] Christophe, S.E., Ferri, M.G. and Hsieh, J. (2008) Informed Trading before Analyst Downgrades: Evidence from Short Sellers. Social Science Electronic Publishing, 95, 85-106. https://doi.org/10.2139/ssrn.1108162

[12] Chen, T., Harford, J. and Lin, C. (2015) Do Analysts Matter for Governance? Evidence from Natural Experiments. Journal of Financial Economics, 115, 383-410. https://doi.org/10.1016/j.jfineco.2014.10.002

[13] Fang, V.W., Huang, A.H. and Karpoff, J.M. (2016) Short Selling and Earnings Management: A Controlled Experiment. Journal of Finance, 71, 1251-1294. https://doi.org/10.1111/jofi.12369

[14] Li, Z., Li, H. and Ma, W. (2017) The Information Governance Effect of Short Selling. Economic Research Journal, No. 11.

[15] Zhang, X, Zhou, P. and Li, C. (2016) Short Selling and Earnings Quality-Evidence from Financial Restatement. Journal of Financial Research, No. 8, 175-190.

[16] Massa, M., Zhang, B. and Zhang, H. (2012) The Invisible Hand of Short Selling: Does Short Selling Discipline Earnings Management? Social Science Electronic Publishing, 28, 1701-1736.

[17] Hou, Q., Jin, Q. and Su, L. (2017) Short Selling and Big Shareholders "Tunneling". China Economic Quarterly, No. 3, 1143-1172.

[18] Xie, D., Lin, L. and Chen, Y. (2012) The Independence of Compensation Committee and Higher Executive Pay Performance Sensitivity-Analysis and Testing Based on the Pay Defense Hypothesis. Management World, No. 1, 121-140.

[19] Jensen, M.C. and Murphy, K.J. (1990) Performance Pay and Top-Management Incentives. Journal of Political Economy, 98, 225-264. https://doi.org/10.1086/261677

[20] Bebchuk, L.A., Fried, J.M. and Walker, D.I. (2002) Managerial Power and Rent Extraction in the Design of Executive Compensation. University of Chicago Law Review, 69, 751-846. https://doi.org/10.2307/1600632

[21] Liu, H. (2017) Control Chain Length and Company Executive Compensation Contract. Management World, No. 3, 95-112.

[22] Lu, R., Liu, J. and Xu, N. (2011) Internal Control, Property Rights and Executive Compensation Performance Sensitivity. Accounting Research, No. 10, 42-48.

[23] Deng, X., Chen, D. and Chen, Y. (2015) The Board Overlaps with the CEO's Luck: Evidence Based on State-Controlled Listed Companies. Accounting Research, No. 7 , 49-55.

[24] Lin, L., Xie, D. and Chen, Y. (2013) Actual Controller Supervision, Industry Competition and Manager Motivation-Empirical Evidence from Privately Listed Companies. Accounting Research, No. 9, 36-43.

[25] Wu, Y. and $\mathrm{Wu}, \mathrm{S}$. (2010) Executive Pay: Incentives or Self-Interest?-Evidence from Chinese Listed Companies. Accounting Research, No. 11, 40-48.

[26] Zhang, M., Ma, L. and Zhang, W. (2013) The Corporate Bond Effect of Corporate Charitable Giving-Empirical Evidence Based on Listed Companies in China. 
Management World, No. 7, 163-171.

[27] Fang, H. and Jin, Y. (2013) Corporate Governance, Internal Control and Non-Efficiency Investment: Theoretical Analysis and Empirical Evidence. Accounting Research, No. 7, 63-69. 